Jurnal Ekonomi dan Perbankan Syariah

Vol. 8. No.2, 0ktober 2020: 22-40, ISSN (cet): 2355-1755 | ISSN (online): 2579-6437

DOI: https://doi.org/10.46899/jeps.v8i2.225

\title{
THE EFFECT OF NON-MUSLIM COMMUNITY'S PERCEPTION ON INTEREST IN BECOMING SYARIAH BANK CUSTOMERS IN THE CITY OF BEKASI, WEST JAVA
}

\author{
Muhammad Rafi Aziz ${ }^{1}$, Atiyah Fitri', \\ Muhammad Doddy $\mathbf{A B}^{3}$
}

${ }^{1}$ SEBI: Email: enokamtis@gmail.com

${ }^{2}$ SEBI Lecturer Email: atiyah.fitri@ sebi.ac.id

${ }^{3}$ SEBI Lecturer \& Doctoral Candidate AeU Malaysia Email: doddy.abe@gmail.com

\begin{abstract}
This study aims to determine whether the cognitive perception, affective perception, and conative perception variables affect the people's interest to become customers of Islamic banks in Bekasi City. It uses quantitative methods. As it uses the Slovin formula, the number of respondents was 100 out of a total population of 320,984 non-Muslim community in Bekasi City. The data analysis in this study adopted Structural Equation Modeling (SEM) with the Partial Least Square (PLS) approach and the data was processed using PLS 3.0. Based on the results of the data analysis, cognitive variables and affective variables do not have a significant effect on the people's interest in becoming customers of Islamic banks in Bekasi City, while the conative variables have a significant effect on the people's interest in becoming customers of Islamic banks in Bekasi City.
\end{abstract}

Keywords: Cognitive Perception, Affective Perception, Conative Perception, people's interest in becoming customers and non-Muslim community

\section{INTRODUCTION}

The emergence of shari'ah-based financial institutions is an important moment in the development of the Islamic economy in Indonesia. It is seen that the development of the Islamic financial system is becoming stronger with the stipulation of the basics of operational law through Law no. 7 of 1992 concerning banking which has been amended in Law no. 10 of 1998 which allows conventional banks to operate based on sharia principles by opening a Sharia Business Unit (UUS) to accelerate the growth of Islamic banking (Master Plan of Indonesian Sharia Financial Architecture, 2015). Then, it is followed by Law no. 23 of 1999, Law no. 9 of 2004 concerning Bank Indonesia, and Law no. 21 of 2008 concerning Islamic banks. This regulatory support from the government provides a great opportunity for the operation of banks using the sharia system. (Machampang, 2009)

According to the Sharia Banking statistical data released by the Financial Services Authority (OJK) in April 2018, there are 13 Islamic Commercial Banks (BUS), 21 Sharia Business Units (UUS), and 168 BPRS with total assets of BUS and UUS of Rp. 423,944 billion. (Https://Business- 
Jurnal Ekonomi dan Perbankan Syariah

Vol. 8. No.2, 0ktober 2020: 22-40, ISSN (cet): 2355-1755 | ISSN (online): 2579-6437

| 23

Law.Binus.Ac.Id/2018/07/03/Perkembangan-Lembaga-Perbankan-Dan-

Keuangan-Syariah-Di-Indonesia).

These figures indicate the significant development of Islamic banking in Indonesia. It is a relief to see the development not only in terms of quantity but also the quality of the systems and services. Previously, Islamic commercial banks and Islamic units were only allowed to serve prospective customers at Islamic branch offices or sub-branch offices. However, since the officechanneling which is based on BI Regulation Number 8/3 / PBI / 2006 and became effective in May 2007, financing services, such as account bookkeeping, deposits, transfers, clearing, and cash withdrawals can be made at commercial bank branches that have sharia units. The application of office-channeling even makes the growth is faster.

Islamic financial institutions represented by Islamic banking are considered by some people as an alternative for people who are already fed up with the capitalist economic system. The capitalist system that has long been globalized which prioritizes personal wealth has an impact on the unequal distribution of wealth. On the other hand, many people still think that the Islamic economic system is only present for Muslim communities. This can be seen from the perception that Islamic financial institutions themselves are only understood as a market for Muslims only, "closed" to non-Muslims. The profit-sharing system which is one of the important elements of the shari'ah market has long been implemented by European countries, especially England (Kartajaya: 2006).

The prohibition of usury for Muslim communities which is clearly stated in the Qur'an Surat Al-Baqarah verses 278-279 is also in line with the ancient book, the Veda, which was raised in ancient India. The Veda is the oldest scriptures of Hinduism before Islam was born. The Vedic teachings condemn usury as a grave sin and prohibit the implementation of interest. Meanwhile, the law based on Christianity states that the prohibition or strict restriction on usury is valid for more than 1400 years (Latifa and Mervyn: 2004, p. 264). Besides, Antonio (2001: 43) states that Jews are prohibited from practicing interest taking. This prohibition is widely found in their holy books, both in the Old Testament and the Talmudic Law. These value equations can be an opportunity for the acceptance of Islamic banks for non-Muslims as a sharia banking market that can be optimized in the future.

Based on the data from the Financial Services Authority (OJK) in 2019, the number of customers of Islamic banks has currently reached 31.89 million people, or around 12 percent of the total Muslim population in Indonesia. The number of Islamic banking customers is considered small, given that the total Muslim population in Indonesia reaches around 227 million people or 87 percent of the total population of Indonesia. This resulted in the low market share of Islamic banking assets, which is 6.01 percent. The low share of the Islamic 
banking market in Indonesia, when compared to neighboring countries such as Malaysia (28 percent), is caused by several things, among other is the low level of Islamic financial literacy (8.93 percent), which affects the low level of Islamic financial inclusion ( 9.1 percent). This condition certainly requires more massive efforts by various stakeholders in building awareness at all levels of society regarding Islamic finance. (Arham: 2020, p. 17).

In terms of developing sharia banking, Bank Indonesia is committed to realizing a modern, universal and open Islamic banking system for all Indonesians. Bank Indonesia has created a grand strategy to increase the Islamic banking market in Indonesia. One of them is the formation of a new image of national Islamic banking that is inclusive and universal (https://www.ojk.go.id/id/kanal/perbank / Pages / Bank Syariah.aspx). With the establishment of this strategy, it is hoped that Islamic banking will be able to absorb a wider market, including non-Muslims in the future.

Bekasi, one of the regencies in West Java, is in the top 5 provinces with the largest distribution of Islamic commercial bank networks.

Table 1. Distribution of Sharia Commercial Bank Network by Region in November 2019

\begin{tabular}{|c|c|c|c|c|}
\hline \multicolumn{5}{|c|}{ Distribution of Sharia Commercial Bank Network by Region } \\
\hline & \multirow[t]{2}{*}{ Bank Group } & $\begin{array}{l}\text { KPO/ } \\
\text { KC } \\
\end{array}$ & $\begin{array}{l}\mathrm{KCP} / \mathrm{U} \\
\mathrm{PS}\end{array}$ & KK \\
\hline & & $\begin{array}{l}\mathrm{HOO} / \\
\mathrm{BO}\end{array}$ & $\begin{array}{l}\text { SBO/S } \\
\text { SU }\end{array}$ & $\mathrm{CO}$ \\
\hline \multicolumn{2}{|c|}{ Sharia Commercial Bank } & 480 & 1.237 & 197 \\
\hline 1 & West Java & 67 & 218 & 27 \\
\hline 2 & DKI Jakarta & 71 & 150 & 35 \\
\hline 3 & Central Java & 37 & 89 & 17 \\
\hline 4 & East Java & 44 & 140 & 22 \\
\hline 5 & Aceh & 38 & 117 & 29 \\
\hline
\end{tabular}

Source: Financial Services Authority Data 2019

Whereas in the city of Bekasi, there are 12 Islamic banks: Bank Syariah Mandiri, Bank Syariah Patriot Bekasi, Bank Syariah Bukopin, Bank Panin Syariah, Bank BNI Syariah, Bank BRI Syariah, Bank Jabar Syariah, Bank Syariah Artha Madani, Bank BTN Syariah, Bank BPR Syariah, Bank Harta Insan Karimah Bekasi, Bank Permata Syariah, Bank SKI KCP Syariah. The data shows that people living in Bekasi have a good market potential for Islamic banks. 
Jurnal Ekonomi dan Perbankan Syariah

Vol. 8. No.2, 0ktober 2020: 22-40, ISSN (cet): 2355-1755 | ISSN (online): 2579-6437

Table 2. Composition of Religion in Bekasi year 2016

\begin{tabular}{|l|l|l|}
\hline No & \multicolumn{1}{|c|}{ Religion } & \multicolumn{1}{c|}{ Total (people) } \\
\hline 1 & Islam & 2.141 .407 \\
\hline 2 & Christianity & 196.985 \\
\hline 3 & Catholic & 71.770 \\
\hline 4 & Buddhism & 22.492 \\
\hline 5 & Hindu & 27.952 \\
\hline 6 & Konghucu & 201 \\
\hline 7 & Belief in one God & 1.584 \\
\hline
\end{tabular}

Source: Central Bureau of Statistics Kota Bekasi 2016

From the data above, the total number of non-Muslim community in Indonesia is 320,984 people. This figure displays the large potential for expansion in the non-Muslim customer market for the Islamic banking market in Bekasi. It will certainly be even greater if the total number of non-Muslims in Indonesia, which reaches 29,568,464 people, is calculated. (2010 Population Census Data - Central Bureau of Statistics of the Republic of Indonesia).

\section{LITERATURE REVIEW}

\section{Perception}

Various experts provide various definitions of perception, although in principle they contain the same meaning. According to (Rakhmat, 2018), perceptions are experiences about objects, events, or relationships obtained by inferring information and interpreting messages. He argued that there are three aspects in perception that are considered relevant to human cognition; sensory recording, pattern recognition, and attention.

Perception is a process that is preceded by a sensing process, which is the process of receiving a stimulus by an individual through the senses or also called a sensory process (Bimo, 2010). These components state that perception contains three components that make up a person's personality as follows:

a) Cognitive components (perceptual components), namely components related to knowledge, views, beliefs, namely things related to how people perceive the object of attitudes.

b) Affective component (emotional component), which is a component related to feeling happy or unhappy with the object of the attitude. Pleasure is a positive thing, while displeasure is a negative thing.

c) The conative component (the behavioral component, or action component), is a component related to the tendency to act on the object of attitude. This component shows the intensity of the attitude, which shows the size of the tendency to act or behave in a person towards the object of attitude. 


\section{Interest}

Interest is a constant tendency to pay attention to and remember some activities (Slameto, 2003). Meanwhile, another opinion says that interest is a feeling of preference and feeling of interest in something or activity, without being told. Interest is also related to the style of movement that encourages a person to face or deal with people, objects, activities, experiences that are stimulated by the activity itself (Djaali, 2008). From some of the opinions expressed by the experts above, the writer defines that interest as a tendency that is closely related to feelings, especially feelings of pleasure towards something that is considered valuable or as needed and gives satisfaction to it. Something that can be in the form of activities, people, experiences, or objects that can be used as stimuli that require a directed response. If something is determined according to his needs or pleasing to him, then it will be done. On the other hand, if something is unpleasant, it will be abandoned. As stated by (Abror, 2010) that interest contains three elements :

a. The element of cognition (knowing) in the sense that interest is preceded by knowledge and information about the object the interest is pointing at.

b. Emotional elements (feelings) because participation or experience is accompanied by certain feelings (usually happy feelings)

c. The element of conation (will) is a continuation of the two elements above, namely manifested in the form of a willingness and desire to carry out an activity.

\section{Sharia Banks and Sharia Bank Customers}

Islamic banks are financial institutions that function to facilitate economic mechanisms in the real sector through business activities (investing, buying and selling, or others) based on Islamic principles, which are the rules of agreements based on Islamic law between banks and other parties for depositing funds or financing business activities. or other activities declared following sharia values that are macro or micro (Dahlan, 2014)

Islamic banking in international terms is also known as Islamic Banking or also known as interest-free banking. Islamic banking was originally developed as a response from a group of economists and Muslim banking practitioners who tried to accommodate the pressure from various parties who wanted to provide financial transaction services that were carried out in line with moral values and Islamic principles. It is mainly related to the prohibition of the practice of usury, maisir (speculation), and gharar (obscurity). (Indonesia, 2001

\section{Previous Researches}

Yupitri and Raina (2012), in their research on the factors that influence non-Muslims to become customers of Islamic banks in Medan, concluded that promotion is the strongest factor in influencing non-Muslim customers to become customers at Bank Syariah Mandiri, followed by products and facilities. 
Meanwhile, Akbar and Haroni's (2013) research related to the perceptions of ethnic Chinese towards Islamic banking in Medan states that there is a need to increase Islamic banking information through seminars on the products, principles, and working mechanisms of Islamic banks. The ethnic Chinese community in Medan who has an interest in business development needs promotion and physical evidence to attract interest as well as socialization about the advantages of Islamic banking as interest in making transactions.

Research on the perceptions of non-Muslim customers towards Islamic banks in Malaysia conducted by Aziz, Rokiah, and Ahmad (2012) resulted that Islamic services and products were well received by non-Muslim residents, especially in Lembah Klang (city area), Malaysia. Islamic banks have become popular and are more widely accepted by the community, especially nonMuslims. The results also show that the majority of respondents have Islamic and conventional bank accounts. Unfortunately, respondents are not sure about the potential of Islamic banking products in the future. This is thought to be caused by the lack of information provided, especially those related to the potential for Islamic banking products that can reduce misunderstandings among the Malaysian public. Non-Muslim respondents who have high education found a high belief that Islamic banking will doIntereste conventional banking in Malaysia. This is due to the ease of access to information about Islamic banking. In this study, it was found that non-Muslims from the age group between 19 35 years old and highly educated had better knowledge and understanding of Islamic banking products and services. This is due to the exposure of news and information that is wider from various sources.

\section{RESEARCH METHODOLOGY}

This research is quantitative. The object of this research was respondents of the Non-Muslim community in Bekasi City with a total sample of 100 people from the total population of the existing Non-Muslim community. There are 2 types of data conducted in this research, namely primary data and secondary data. The primary data consist of interviews and questionnaires filled out by non-Muslim communities in Bekasi City. Secondary data includes data taken from various kinds of literature such as journals, books, or articles from the internet.

The sampling technique used was non-probability sampling. The data analysis technique used is a quantitative analysis using the SEM (Structural Equation Modeling) model or the Structural Equation Modeling with the variance result in structural equation test tool or better known as the Partial Least Square (PLS).

PLS model evaluation is done by evaluating the outer model and inner model. The outer model is a measurement model to assess the validity and reliability of the model. Through the algorithmic literacy process, the measurement model parameters (convergent validity, discriminant validity, composite reliability, and Cronbach alpha) were obtained, especially the R2 value as a parameter of the prediction model accuracy. Inner model is a structural model to predict the causality relationship between latent variables. Through the 
bootstrapping process, T-Statistic test parameters are obtained to predict a causal relationship (Jogiyanto, 2015).

The outer model was tested using the Convergent Validity test with the indicator considered valid if it had a score of AVE (Average Variance Extranced) $>0.5$ and also a loading factor value $>0.7$. After that, a second test, Discriminant Validity, was performed, to assess based on cross-loading, the model had sufficient discriminant validity if the cross-loading value between the constructs was greater than the cross-loading value between the constructs and other constructs in the model (Jogiyanto, 2009). The last one is testing the reliability through the Cronbach Alpha value and Composite Reliability. A constructor variable is said to be reliable if it provides a Cronbach alpha value> 0.7 and composite reliability> 0.7 (Jogiyanto, 2015).

In evaluating the inner model in this study, the Coefficient of DeterInterestion and the Path Coefficient is used. The coefficient of deterInterestion on the construct is called the R-square value. Meanwhile, the path coefficient is the influence of latent constructs that we can find out through the Bootstrapping procedure. The variable is said to have a significant effect if the t-statistic value is greater than the t-table, in this study the t-table is 1.96. To see the t-statistic results in SmartPLS, it can be obtained through bootstrapping results. The hypothesis is accepted if the t-statistic is $>1.96$ and vice versa, the hypothesis is rejected if the t-statistic is $<1.96$ (Jogiyanto, 2015).

\section{Based on gender}

In this study, gender is categorized into male and female. The data and percentages regarding the gender of non-Muslim respondents in Bekasi City are as follows:

\begin{tabular}{|l|l|l|}
\hline Gender & Score & Percentage \\
\hline Man & 45 & $45 \%$ \\
\hline Woman & 55 & $55 \%$ \\
\hline Total & 100 & $100 \%$ \\
\hline
\end{tabular}

Based on the information in the table above, it can be seen that the majority of respondents consists of 55 women, or $55 \%$, while the rest are male as many as 45 people or $45 \%$. This shows that the sample taken for this study is that women are more dominant than men.

\section{Based on Age}

Respondents taken as samples in this study were grouped into 4; 19-29 years, 30-39 years, 40-49 years, and 50 years and over. The data and percentages regarding the age of non-Muslim respondents in Bekasi City are as follows:

\begin{tabular}{|l|l|l|}
\hline Age & Score & Percentage \\
\hline $19-29$ years old & 83 & $83 \%$ \\
\hline $30-39$ years old & 9 & $9 \%$ \\
\hline $40-49$ years old & 6 & $6 \%$ \\
\hline
\end{tabular}


Jurnal Ekonomi dan Perbankan Syariah

Vol. 8. No.2, 0ktober 2020: 22-40, ISSN (cet): 2355-1755 | ISSN (online): 2579-6437

| 29

\begin{tabular}{|l|l|l|}
\hline$>50$ years old & 2 & $2 \%$ \\
\hline Total & 100 & $100 \%$ \\
\hline
\end{tabular}

From the table above, it can be seen that most respondents are aged 1929 years, consisting of 83 people or $83 \%$. Age 30-39 years consists of 9 people or $9 \%$. Age 40-49 years consists of 6 people or $6 \%$. And the least respondents are aged $>50$ years, as many as 2 people or 2\%. This shows that 19-29 years of age are the dominant ones taken as the research sample.

\section{Based on recent education}

Respondents taken as samples in this study were grouped into 4 groups, namely High School Education, Last Education D3, Last Education S1, Last Education S2 / S3. And the percentage regarding the age of non-Muslim respondents in Bekasi City is as follows:

\begin{tabular}{|l|l|l|}
\hline Education background & Score & Percentage \\
\hline High School & 62 & $62 \%$ \\
\hline D3 & 11 & $11 \%$ \\
\hline S1 & 17 & $17 \%$ \\
\hline S2/S3 & 10 & $10 \%$ \\
\hline Total & 100 & $100 \%$ \\
\hline
\end{tabular}

From the table, it is known that most respondents are high school students, consisting of 62 people or $62 \%$. S1 degree consists of 17 people or $17 \%$. Then, D3 degree is 11 people or $11 \%$. And the least number is the respondent with S2 / S3 degrees consisting of 10 people or $10 \%$. This shows that respondents with high school education are the most dominant compared to the others.

\section{Based on monthly income}

The respondent's monthly income can be different for people who are interested in becoming a customer of an Islamic bank. The data and presentations regarding the monthly income of non-Muslim respondents in Bekasi City are as follows: 
30 | Muhammad Rafi Aziz, Atiyah Fitri, M. Doddy AB: The Effect Of Non-Muslim Community's Perception On Interest In Becoming Syariah Bank Customers In The City of Bekasi, West Java

\begin{tabular}{|l|l|l|}
\hline Monthly income & Score & Percentage \\
\hline$<$ Rp. 2.000.000 & 54 & $54 \%$ \\
\hline Rp. 2.000.000-Rp. 3.000.000 & 13 & $13 \%$ \\
\hline Rp. 3.000.000-Rp. 4.000.000 & 9 & $9 \%$ \\
\hline Rp. 4.000.000-Rp. 5.000.000 & 12 & $12 \%$ \\
\hline$>$ Rp. 6.000.000 & 12 & $12 \%$ \\
\hline Total & 100 & $100 \%$ \\
\hline
\end{tabular}

Based on the information in the table above, it can be seen that the most dominant respondents based on the amount of monthly income are $<\mathrm{Rp}$. 2,000,000, consisting of 54 people or 54\%. Then Rp. 2,000,000 - Rp. 3,000,000, consists of 13 people or $13 \%$, Rp. 4,000,000 - Rp. 5,000,000 has the same value and percentage as> Rp. 6,000,000, consisting of 12 people or $12 \%$, and the minimum amount is Rp. 3,000,000 - Rp. 4,000,000, consists of 9 people or $9 \%$. This shows that the most dominant respondent's monthly income is $<\mathrm{Rp}$. $2,000,000$.

\section{Based on Occupation}

Respondents taken as samples in this study were grouped into 4 groups, namely students, civil servants/military/police, private employees, and entrepreneurs/business people. The data and percentages regarding the work of non-Muslim respondents in Bekasi City are as follows:

\begin{tabular}{|l|l|l|}
\hline Occupation & Score & Percentage \\
\hline Student & 65 & $65 \%$ \\
\hline PNS/TNI/POLRI & 10 & $10 \%$ \\
\hline Private employees & 19 & $19 \%$ \\
\hline Entrepreneur/Business people & 6 & $6 \%$ \\
\hline Total & 100 & $100 \%$ \\
\hline
\end{tabular}

From the table, it is known that the most respondents are students, consisting of 65 people or $65 \%$, private employees are 19 people or $19 \%$. Then the PNS / TNI / POLRI consists of 10 people or $10 \%$. And the least number of respondents with jobs as entrepreneurs/business people is as many as 6 people or $6 \%$. The above shows that the respondent's occupation is dominated by students.

\section{Based on Religion}

Respondents taken as samples from this study were divided into 4 groups; Catholic, Protestant, Hindu, Buddhist. The data and percentage regarding non-Muslim religions in Bekasi City are as follows: 
Jurnal Ekonomi dan Perbankan Syariah

Vol. 8. No.2, 0ktober 2020: 22-40, ISSN (cet): 2355-1755 | ISSN (online): 2579-6437

| 31

\begin{tabular}{|l|l|l|}
\hline Religion & Score & Percentage \\
\hline Catholic & 27 & $27 \%$ \\
\hline Protestant & 48 & $48 \%$ \\
\hline Hindu & 11 & $11 \%$ \\
\hline Budha & 14 & $14 \%$ \\
\hline Total & 100 & $100 \%$ \\
\hline
\end{tabular}

From the table above it can be seen that the respondents are mostly Protestants consisting of 48 people or $48 \%$, Catholics are 27 people or $27 \%$, Buddhists are 14 people or $14 \%$, Hindus are 11 people or $11 \%$. The above shows that Protestant is the most dominant religion among other religions

\section{Based on the frequency of visiting houses of worship in a week}

Respondents taken as the sample of this study are divided into 4 groups, namely once, twice, more than 2 times, and never. The data and percentages regarding the frequency of visits to places of worship are as follows

\begin{tabular}{|l|l|l|}
\hline Frequency & Score & Percentage \\
\hline Once & 74 & $74 \%$ \\
\hline Twice & 13 & $13 \%$ \\
\hline More than twice & 7 & $7 \%$ \\
\hline Never & 6 & $6 \%$ \\
\hline Total & 100 & $100 \%$ \\
\hline
\end{tabular}

From the table above, it is known that the majority of respondents visiting houses of worship are once in a week consisting of 74 people or $74 \%$, twice in a week are 13 people or $13 \%$, more than 2 times in a week, are 7 people or $7 \%$ and never are 6 people or $6 \%$.

\section{Based on activeness in religious organization programs}

Respondents who were used as samples of this study were divided into 4 groups, namely very active, active, sometimes, and inactive. The data and frequency regarding activeness in religious organization programs are as follows:

\begin{tabular}{|l|l|l|}
\hline Activeness & Score & Percentage \\
\hline Very active & 10 & $10 \%$ \\
\hline Active & 27 & $27 \%$ \\
\hline Sometimes & 31 & $31 \%$ \\
\hline Never & 32 & $32 \%$ \\
\hline Total & 100 & $100 \%$ \\
\hline
\end{tabular}

From the table above, it is known that the majority of respondents related to activeness in religious organization program is dominated by never 
active, consisting of 32 people or $32 \%$, sometimes active are 31 people or $31 \%$, active are 27 people or $27 \%$ and very active are 10 people or $10 \%$. Therefore, it can be concluded that respondents who have never participated in religious organization program activities are more dominant than others.

\section{Based on decision making with religious values}

Respondents drawn from this study were divided into 3 groups, namely Yes, No, and Maybe. The data or frequency regarding decision making with religious values are as follows:

\begin{tabular}{|l|l|l|}
\hline Decision & Score & Frequency \\
\hline Yes & 62 & $62 \%$ \\
\hline No & 7 & $7 \%$ \\
\hline Maybe & 31 & $31 \%$ \\
\hline Total & 100 & $100 \%$ \\
\hline
\end{tabular}

From the table above it can be seen that the majority of respondents in making decisions with religious values, namely with the 'Yes' answer are 62 people or $62 \%$, the 'maybe' answer 31 people or $31 \%$ and the 'No'answer are 7 people or $7 \%$. Therefore the majority of respondents in making decisions with religious values are 'Yes' answers because the answer to Yes is more dominant than the others.

\section{Average Variance Extracted (AVE)}

AVE is one of the parameters to assess convergent validity. The latent variable is said to be valid if the AVE value must be more than 0.5. The recommended AVE value must be more than 0.5 , meaning that $50 \%$ or more of the variance of the indicator can be explained. AVE values can be seen as follows:

\begin{tabular}{|l|l|l|}
\hline Variable & AVE & Information \\
\hline Interest & 0.740 & Valid \\
\hline Affective Perception & 0.551 & Valid \\
\hline Cognitive Perception & 0.551 & Valid \\
\hline Conative Perception & 0.611 & Valid \\
\hline
\end{tabular}


Jurnal Ekonomi dan Perbankan Syariah

Vol. 8. No.2, 0ktober 2020: 22-40, ISSN (cet): 2355-1755 | ISSN (online): 2579-6437

| 33

Based on the table above, all variables meet the AVE criteria, namely the AVE value is above 0.50 , therefore, all variables are declared valid.

\section{Discriminant validity}

The discriminant validity test relates to the principle that the gauges (manifest variables) of different constructs should not communicate with high (Latan, 2012). The way to test discriminant validity with reflective indicators is to compare the square root of the AVE for each construct with the correlation value between constructs in the model. Good discriminant validity shown from the square root of AVE for each construct is greater than the correlation between constructs in the model. Below the table shows the estimation results of the latent variable correlation calculations

\begin{tabular}{|l|l|l|l|l|}
\hline & Interest & $\begin{array}{l}\text { Affective } \\
\text { Perception }\end{array}$ & $\begin{array}{l}\text { Cognitive } \\
\text { Perception }\end{array}$ & $\begin{array}{l}\text { Conative } \\
\text { Perception }\end{array}$ \\
\hline Interest & 1.000 & 0.555 & 0.341 & 0.727 \\
\hline Affective Perception & 0.555 & 1.000 & 0.604 & 0.697 \\
\hline Cognitive Perception & 0.341 & 0.604 & 1.000 & 0.507 \\
\hline Conative Perception & 0.727 & 0.697 & 0.507 & 1.000 \\
\hline
\end{tabular}

The AVE and AVE root is presented in the table below:

\begin{tabular}{|l|l|l|}
\hline & AVE & Akar AVE \\
\hline Interest & 0.740 & 0.860 \\
\hline Affective Perception & 0.551 & 0.742 \\
\hline Cognitive Perception & 0.551 & 0.742 \\
\hline Conative Perception & 0.611 & 0.781 \\
\hline
\end{tabular}

The maximum correlation between the constructs of interest level and the other constructs was 0.727 and the AVE root value was 0.860 . The maximum correlation of the affective perception level constructs of the other constructs is 0.697 and the AVE root value is 0.742 . The maximum correlation between the constructs of cognitive perception level and other constructs is 0.604 and the AVE root value is 0.742 . The maximum correlation of the constructs of the level of conative perception to the other constructs was 0.727 and the AVE root value was 0.781 . So it can be concluded that all constructs have a good discriminant validity value because the AVE root value for all constructs is greater than the correlation value between all existing constructs.

\section{Reliability Test}

A reliability test is conducted to prove the accuracy, consistency, and accuracy of the instrument in measuring constructs. PLS-SEM uses the SmartPLS 3.0 program. To measure the reliability of a construct with reflective indicators can be done in two ways; by looking at the value of Cronbach's Alpha and by considering the Composite Reliability. The construct is declared reliable 
if the Cronbach's Alpha and Composite Reliability values are above 0.70 . The following is the output of the Cronbach's Alpha and Composite Reliability values using SmartPLS 3

\begin{tabular}{|l|l|l|}
\hline Information & Composite Reliability & Cronbach's Alpa \\
\hline Interest & 0.934 & 0.912 \\
\hline Affective Perception & 0.879 & 0.837 \\
\hline Cognitive Perception & 0.858 & 0.823 \\
\hline Conative Perception & 0.903 & 0.871 \\
\hline
\end{tabular}

Based on the results of data processing in the table above, the composite reliability and Cronbach's alpha values of all constructs are above 0.70 . This value indicates that the consistency and stability of the instruments used are very high, so the constructs or variables in this research model have become a fit measurement tool and all questions asked of respondents to measure each construct in the study are reliable questions. So it can be concluded that each construct used in this research model has a good level of reliability.

\section{Structural Equation Model (SEM) Test}

The method of testing the hypothesis in this study is to use the variancebased Structural Equation Model (SEM) using SmartPLS 3.0. The following are the results of the SEM Algorithm Full Model test in the Figure below:

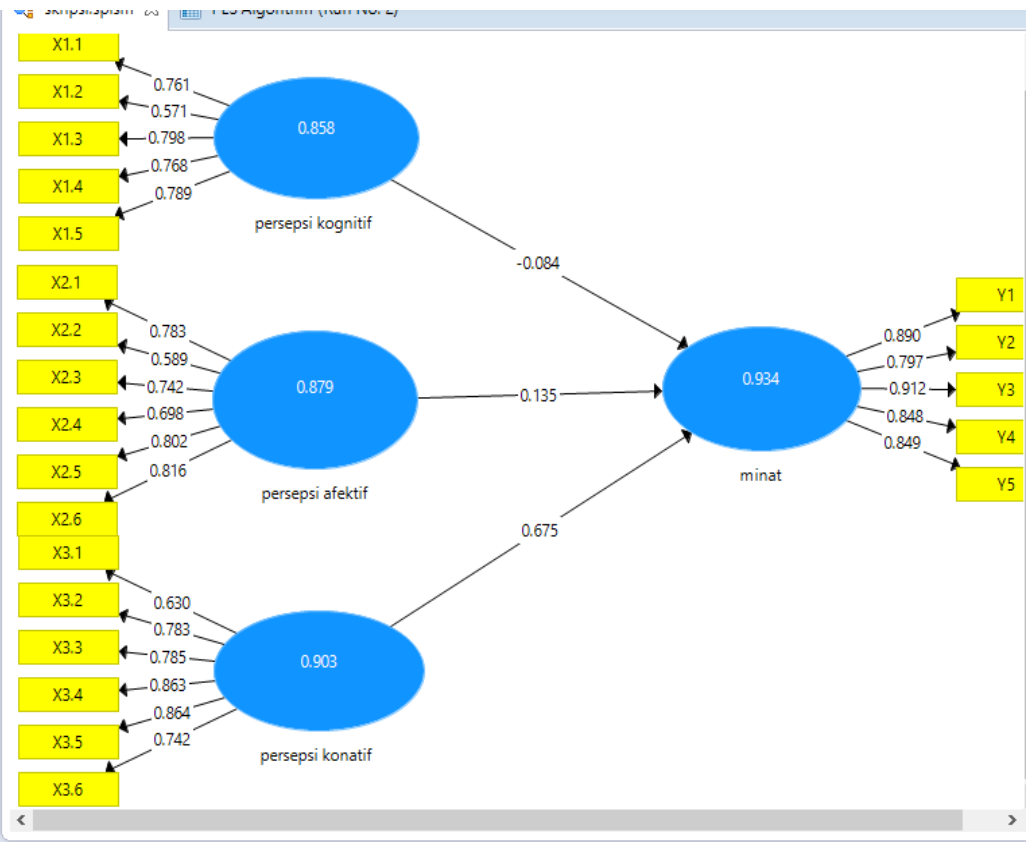


Jurnal Ekonomi dan Perbankan Syariah

Vol. 8. No.2, 0ktober 2020: 22-40, ISSN (cet): 2355-1755 | ISSN (online): 2579-6437

| 35

This study uses 1 endogenous variable (dependent variable), 3 exogenous variables (independent variable), and 22 indicators. The indicator used in this study is reflective so that the direction of the causality relationship comes from the construct to the indicator.

\section{Hypothesis testing}

Hypothesis testing is done by looking at the path coefficient value which shows the parameter coefficient and the value of the t-statistic. The significant parameter estimated provides information about the relationship between the variable variables in the study and then compares the t-statistic value with the t-table value. If the T-statistic is higher than the T-table value, it means that the hypothesis is supported or accepted. In this study for a confidence level of 95 percent (alpha 95 percent), the T-table value for the one-tailed hypothesis was $>1.96$. The table below presents the results of the path coefficient test with SmartPLS 3.0.

\begin{tabular}{|l|r|r|r|r|r|} 
& Original Sampl... & Sample Mean $(\ldots$ & Standard Devia... & T Statistics (10/... & P Values \\
\hline persepsi afektif... & 0.135 & 0.163 & 0.164 & 0.822 & 0.413 \\
\hline persepsi kognit... & -0.084 & -0.053 & 0.087 & 0.966 & 0.336 \\
\hline persepsi konati... & 0.675 & 0.645 & 0.110 & 6.114 & 0.000 \\
\hline
\end{tabular}

i. Affective perceptions positively affect the interest of the non-Muslim community to become customers of Islamic banks

Based on the results of the resampling bootstrapping test, the coefficient parameter value for the affective perception variable on the interest of nonMuslims to become customers of Islamic banks is 0.135 with a t-statistic value of 0.822 . This shows that affective perceptions do not have a significant effect on the interest of non-Muslims to become customers of Islamic banks because the t-statistic value is smaller than 1.96. Besides, the influence of the affective perception variable on the interest of non-Muslims to become customers of Islamic banks is positive because the value of the coefficient parameter is positive. So it can be concluded that $\mathrm{H} 1$ is rejected because affective perceptions have a positive and insignificant relationship to the interest of non-Muslims to become customers of Islamic banks.

ii. Cognitive perceptions affect the interest of non-Muslim people to become customers of Islamic banks negatively

Based on the results of the resampling bootstrapping test, the coefficient parameter value for the cognitive perception variable on the interest of non- 
Muslims to become customers of Islamic banks is -0.084 with a t-statistic value of 0.966 . This shows that cognitive perceptions do not have a significant effect on the interest of non-Muslims to become customers of Islamic banks because the t-statistic value is smaller than 1.96. Besides, the influence of cognitive perception variables on the interest of non-Muslims to become customers of Islamic banks is negative because the coefficient parameter is negative. So it can be concluded that $\mathrm{H} 2$ is rejected because cognitive perceptions have a negative and insignificant relationship to the interest of non-Muslims to become customers of Islamic banks.

iii. Conative perceptions affect the interest of non-Muslim people to become customers of Islamic banks positively

Based on the results of the resampling bootstrapping test, the coefficient parameter value for the conative perception variable on the interest of nonMuslims to become customers of Islamic banks was 0.675 with a t-statistic value of 6.114. This shows that the conative perception has a significant effect on the interest of the non-Muslim community to become customers of Islamic banks because the t-statistic value is greater than 1.96. Besides, the influence of the conative perception variable on the interest of non-Muslims to become customers of Islamic banks is positive because the coefficient parameter value is positive. So it can be concluded that $\mathrm{H} 3$ is accepted because the conative perception has a positive and significant relationship to the interest of nonMuslims to become customers of Islamic banks.

\section{DISCUSSION}

\section{Affective Perception Has a Positive Relationship and Has No Significant Influence on the Interest of Non-Muslim Communities to Become Sharia Bank Customers}

Affective perceptions, namely perceptions related to pleasure and displeasure. So, it is directly related to cultural values or the value system it has. Hypothesis 1 (H1) states that affective perception does not have a significant effect on the interest of non-Muslims to become customers of Islamic banks is rejected. Based on the results of the resampling bootstrapping test, the coefficient parameter value for the affective perception variable on the interest of nonMuslims to become customers of Islamic banks is 0.135 with a t-statistic value of 0.822 . This shows that affective perceptions do not have a significant effect on the interest of non-Muslims to become customers of Islamic banks because the t-statistic value is smaller than 1.96. Besides, the influence of the affective perception variable on the interest of non-Muslims to become customers of Islamic banks is positive because the value of the coefficient parameter is positive. So it can be concluded that $\mathrm{H} 1$ is rejected because affective perceptions have a positive and insignificant relationship to the interest of non-Muslims to become customers of Islamic banks.

Another reason why affective perceptions do not have a positive and insignificant effect on the interest of non-Muslim people to Islamic banks is that 
Jurnal Ekonomi dan Perbankan Syariah

Vol. 8. No.2, 0ktober 2020: 22-40, ISSN (cet): 2355-1755 | ISSN (online): 2579-6437

\section{| 37}

the non-Muslim community do not feel the benefits of the existence of Islamic banking in Indonesia, and it is difficult to judge whether they are happy or not happy with Islamic banking because of this affective perception. related to a person's emotional level as well as the sense of belonging. Therefore, the results of this study indicate that the affective perception of the non-Muslim community in Bekasi City does not have a significant effect on the interest of the nonMuslim community to Islamic banks, with a t-statistic value of less than 1.96, which is 0.822 .

\section{Cognitive Perception Has a Negative Relationship and Has No Significant Effect on the Interest of Non-Muslims to Become Customers of Islamic Bank}

Cognitive perceptions are perceptions that are consisting of knowledge or information a person has about the object of his/her attitude. From experience, then a belief will be shaped toward the object of the attitude.

Hypothesis 2 (H2) which states that cognitive perception has no significant effect on the interest of non-Muslims to become customers of Islamic banks is rejected. Based on the results of the resampling bootstrapping test, the coefficient parameter value for the cognitive perception variable on the interest of non-Muslims to become customers of Islamic banks is -0.084 with a t-statistic value of 0.966 . This shows that cognitive perceptions do not have a significant effect on the interest of non-Muslims to become customers of Islamic banks because the t-statistic value is smaller than 1.96. Besides, the influence of cognitive perception variables on the interest of non-Muslims to become customers of Islamic banks is negative because the coefficient parameter is negative. So, it can be concluded that $\mathrm{H} 2$ is rejected because cognitive perceptions have a negative and insignificant relationship to the interest of nonMuslims to become customers of Islamic banks.

Another reason why cognitive perceptions show a negative value and do not have a significant effect on the interest of non-Muslim people to Islamic banks is that this cognitive perception is related to knowledge, views, and beliefs toward an object. The non-Muslim community does not know about the essence of Islamic banking, because the non-Muslim community thinks that Islamic banks are only open to the Muslim community with the label "Syariah" in it. They are not well-informed on how the system in Islamic banks works as well as the difference between conventional banks (commercial banks) and Islamic banks, therefore the non-Muslim community is less sure about saving in Islamic banks. The results of this study also show that the cognitive perception of the non-Muslim community in the city of Bekasi has no significant effect on the interest of the non-Muslim community in Bekasi City with a t-statistic value less than 1.96 , which is 0.966 . 


\section{Conative Perception Has a Positive Relationship and Has a Significant Influence on the Interest of Non-Muslim Community to Become Customers of Islamic Bank}

Conative perception is a person's perception to behave concerning the object of his attitude. Hypothesis 3 (H3) which states that cognitive perception has a significant effect on the interest of non-Muslims to become customers of Islamic banks is accepted. Based on the results of the resampling bootstrapping test, the coefficient parameter value for the conative perception variable on the interest of non-Muslims to become customers of Islamic banks was 0.675 with a t-statistic value of 6.114. This shows that the conative perception has a significant effect on the interest of the non-Muslim community to become customers of Islamic banks because the t-statistic value is greater than 1.96. Besides, the influence of the conative perception variable on the interest of nonMuslims to become customers of Islamic banks is positive because the coefficient parameter value is positive. So, it can be concluded that $\mathrm{H} 3$ is accepted because the conative perception has a positive and significant relationship to the interest of non-Muslims to become customers of Islamic banks. The definition of conative perception is a person's perception of behavior related to the object of his attitude. The results of this study also show that the conative perception of the non-Muslim community in the city of Bekasi has a significant effect on the interest of the non-Muslim community in Bekasi City with a t-statistic value of more than 1.96 , which is 6.114 .

\section{CONCLUSION}

The first hypothesis (H1) proposed by the author which states that affective perceptions have a positive effect on the interest of non-Muslims to become customers of Islamic banks is accepted. The test results using the SmartPLS 3.0 software showed that the value of the statistic was $0.822<1.96$. So, it can be concluded that affective perception has a positive relationship but does not have a significant effect on the interest of non-Muslims to become customers of Islamic banks.

The second hypothesis (H2) proposed by the researchers which states that cognitive perceptions have a close relationship with the interest of nonMuslims to become customers of Islamic banks is rejected. The test results using the SmartPLS 3.0 software show that the t-statistic value is $0.966<1.96$. So, it can be concluded that cognitive perceptions have a close relationship and do not have a significant effect on the interest of non-Muslims to become customers of Islamic banks.

The third hypothesis $(\mathrm{H} 3)$ proposed by the researchers which states that conative perceptions have a positive effect on the interest of non-Muslims to become customers of Islamic banks is accepted. The test results using the SmartPLS 3.0 software show that the t-statistic value is $6.114>1.96$. So it can be concluded that the conative perception has a positive relationship and has a significant effect on the interest of non-Muslims to become customers of Islamic banks. 
Jurnal Ekonomi dan Perbankan Syariah

Vol. 8. No.2, 0ktober 2020: 22-40, ISSN (cet): 2355-1755 | ISSN (online): 2579-6437

| 39

From the results above, it can be concluded that the non-Muslim community in Bekasi City has a positive value in acting to become customers of Islamic banks, but their lack of knowledge about Islamic banks and their lack of emotional feeling towards Islamic banks hinder their actions. If they have knowledge and preference toward Islamic banks, it is not impossible that they will be interested in becoming customers of Islamic banks in Bekasi City.

\section{REFERENCES}

Abror, A. (2010). Psikologi Pendidikan. Yogyakarta: Tiara Wacana.

Aziz, Abdul Abdullah, Rokiah Sidek dan Ahmad Azrin Adnan. (2012). Perception of Non-Muslims Customers towards Islamic Banks in Malaysia, International Journal of Business and Social Science.

Ana, Lely Ferawati Ekaningsih dan Risma Eka Riana, Faktor Interest Non Muslim Menjadi Nasabah Di Bank Syariah. Institut ReligionIslam Darussalam Blokagung Banyuwangi

Antonio, M. Syafi'i. (2001). Bank Syari'ah: dari Teori dan Praktek. Jakarta. Gema Insani Press. Cet. I.

Arham, Muhammad, Ph.D. (2020). Syariah Menuju Era Banking 4.0, Insight Edisi Kedelapan I Januari.

Ascarya. (2007). Akad dan Produk Bank Syariah . Jakarta: Raja Grafindo Persada.

Bimo, W. (2010). Pengantar Psikologi Umum. Jakarta: Andi Offest.

Dahlan, R. (2014, Oktober). Pengaruh Tingkat Bonus Sertifikat Bank Indonesia Syariah Dan Tingkat Inflasi Terhadap Pembiayaan Bank Syariah Di Indonesia. Jurnal Ekonomi 13 dan 2.

Djaali. (2008). Psikologi Pendidikan. Jakarta : Bumi Aksara .

Data Sensus Penduduk 2010 - Badan Pusat Statistik Republik Indonesia

Indonesia, B. (2001). Potensi, Preferensi dan Perilaku Masyarakat terhadap Bank Syariah di Sumatera.Barat.

Irawan, H. (2009). Analisis Faktor-Faktor Yang Mempengaruhi Interest Nasabah Dalam Memutuskan Menabung di Bank Syariah Mandiri Cabang Malang. Skripsi.

Jogiyanto, A. \&. (2015). Partial Least Square (PLS) Struktural Equation Modelling (SEM). Jakarta: CV Andi .

Total Kependudukan menurut Agama. (2016, Desember ). Retrieved from Badan Pusat Statistik

https://bekasikota.bps.go.id/statictable/2016/12/20/43/Total-

penduduk-menurut-agama-.html

Karim, a. (2017). Bank Islam. Analisa Fiqh dan Keuangan.

Kartajaya, Hermawan dan Muhammad Syakir Sula, Syari'ah Marketting, Bandung: PT Mizan Pustaka, 2006, hlm xxv.Latifa, Algaoud, M. dan Mervyn K.Lewis. (2004). Perbankan Syariah; Prinsip, Praktik, dan Prospek, Jakarta: PT.Serambi Ilmu Semesta. 
40 | Muhammad Rafi Aziz, Atiyah Fitri, M. Doddy AB: The Effect Of Non-Muslim Community's Perception On Interest In Becoming Syariah Bank Customers In The City of Bekasi, West Java

Mahmud, D. (2018). Psikologi Suatu Pengantar. Yogyakarta: 1st Published .

Machmudah, Rifa'atul, Faktor-Faktor Yang Mempengaruhi Interest Nasabah Non Muslim Menjadi Nasabah Di Bank Syariah (Studi Pada Bank Cimb Niaga Syariah Cabang Semarang), Jurusan Ekonomi Islam Fakultas Syari'ah IAIN Semarang, (2009)

Mappiare, A. (2010). Psikologi Remaja. Surabaya: Usaha Nasional.

Newswire (Ed.). (2011, Agustus 23). Bisnis Jabar. Retrieved November Rabu , 2019 ,

frombandung.bisnis.com:https://bandung.bisnis.com/read/20110823/5 50/951243/bank-syariah-di-bali-tumbuh-152

https://www.ojk.go.id/id/kanal/perbankan/Pages/Bank Syariah.aspx)

P.Situmorang, A. (2019, Desember Senin). Merdeka.com. Retrieved Februari Senin, 2020, from Per Oktober, OJK Catat Total Nasabah Bank Syariah Capai 31,89 Juta:https://www.merdeka.com/uang/per-oktober-ojkcatat-Total nasabah-bank-syariah-capai-3189-juta.html

Rakhmat, J. (2018). Psikologi Komunikasi. Bandung: PT Remaja Rosdakarya.

Raufan, Handityo. (2016). Persepsi Masyarakat Non-Muslim Terhadap Bprs Dan Bmt (Studi Pada Masyarakat Non Muslim Di Kecamatan Cipanas. Skripsi Slameto. (2003). Belajar dan Faktor yang Mempengaruhinya. Jakarta : Rineka Cipta .

Sugiyono. (2012). Metode Penelitian Kuantitatif, Kualitatif, dan Kombinasi Mixed Method. Bandung: Alfabeta.

Tika, M. P. (2006). Metologi Riset Bisnis. Jakarta: PT.Bumi Aksara.

Yupitri, Evi dan Raina Linda Sari (2012). Analisis Faktor Faktor Yang Mempengaruhi Non Muslim Menjadi Nasabah Bank Syariah Di Kota Medan. 